\title{
Polycyclic aromatic hydrocarbons and development of respiratory and cardiovascular diseases in workers
}

\author{
Hidrocarbonetos policíclicos aromáticos e desenvolvimento de doenças respiratórias e cardiovasculares em trabalhadores \\ Hidrocarburos policíclicos aromáticos y desarrollo de enfermedades respiratorias y cardiovasculares en trabajadores
}

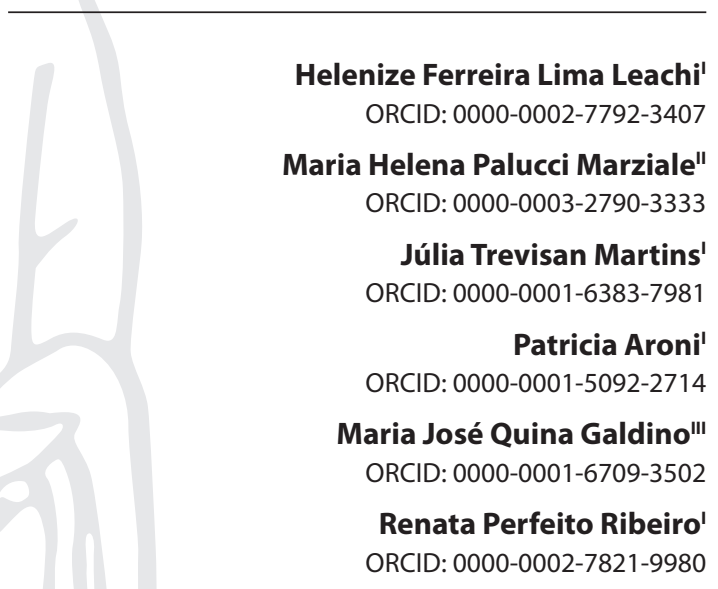

'Universidade Estadual de Londrina. Londrina, Paraná, Brazil. "Universidade de São Paulo. Ribeirão Preto, São Paulo, Brazil. "'Universidade Estadual do Norte do Paraná. Bandeirantes, Paraná, Brazil.

How to cite this article: Leachi HFL, Marziale MHP, Martins JT, Aroni P, Galdino MJQ, Ribeiro RP. Polycyclic aromatic hydrocarbons and development of respiratory and cardiovascular diseases in workers. Rev Bras Enferm. 2020;73(3):e20180965. doi: http://dx.doi.org/10.1590/0034-7167-2018-0965

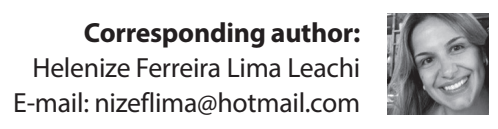

EDITOR IN CHIEF: Antonio José de Almeida Filho ASSOCIATE EDITOR: Priscilla Valladares Broca

Submission: 02-20-2019

Approval: 06-05-2019

\begin{abstract}
Objectives: to identify the scientific evidence on the development of cardiovascular and respiratory diseases due to workplace contamination by polycyclic aromatic hydrocarbons. Methods: integrative literature review. The search for primary articles was held in October 2017 in the Medical Literature Analysis and Retrieval System Online (through Pubmed), Web of Science and Latin American and Caribbean Literature in Health Sciences (LILACS). Results: the 16 studies analyzed showed that exposure to polycyclic aromatic hydrocarbons was associated with cardiovascular diseases, such as increased blood pressure, heart rate variation, and ischemic heart disease; and respiratory disorders, such as decreased lung function, chronic obstructive pulmonary disease, asthma, wheeze, coughing, pulmonary wheezing, chest tightness, effort dyspnea, and sore throat. Conclusions: polycyclic aromatic hydrocarbons cause deleterious effects on the cardiovascular and respiratory systems through mutations and cellular inflammation, being a risk to exposed individuals. Descriptors: Workers; Polycyclic Aromatic Hydrocarbons; Volatile Organic Compounds; Cardiovascular Diseases; Respiratory Diseases.
\end{abstract}

\section{RESUMO}

Objetivos: identificar as evidências científicas sobre o desenvolvimento de doenças cardiovasculares e respiratórias devido à contaminação no ambiente de trabalho por hidrocarbonetos policíclicos aromáticos. Métodos: revisão integrativa da literatura. A busca dos artigos primários foi realizada em outubro de 2017 na Medical Literature Analysis and Retrieval System Online (via Pubmed), Web of Science e Literatura Latino-Americana e do Caribe em Ciências da Saúde. Resultados: os 16 estudos analisados mostraram que a exposição aos hidrocarbonetos policíclicos aromáticos esteve associada a doenças cardiovasculares como aumento da pressão arterial, variação da frequência cardíaca e doença cardíaca isquêmica; e respiratórias como diminuição da função pulmonar, doença pulmonar obstrutiva crônica, asma, chiado, tosse, sibilância pulmonar, opressão no peito, dispneia ao esforço e dor de garganta. Conclusões: os hidrocarbonetos policíclicos aromáticos causam efeito deletério no sistema cardiovascular e respiratório por meio de mutações e de inflamações celulares, sendo um risco ao indivíduo exposto.

Descritores: Trabalhadores; Hidrocarbonetos Policíclicos Aromáticos; Compostos Orgânicos Voláteis; Doenças Cardiovasculares; Doenças Respiratórias.

\section{RESUMEN}

Objetivos: identificar las evidencias científicas sobre el desarrollo de enfermedades cardiovasculares y respiratorias debido a la contaminación en el ambiente de trabajo por hidrocarburos policíclicos aromáticos. Métodos: revisión integrativa de la literatura. La búsqueda de los artículos primarios se realizó en octubre de 2017 en: Medical Literature Analysis and Retrieval System Online (vía PubMed), Web of Science y Literatura Latinoamericana y del Caribe en Ciencias de la Salud. Resultados: los 16 estudios analizados mostraron que la exposición a los hidrocarburos policíclicos aromáticos estuvo asociada a las enfermedades cardiovasculares, como aumento de la presión arterial, variación de la frecuencia cardíaca y enfermedad cardiaca isquémica; y a la respiración, como disminución de la función pulmonar, enfermedad pulmonar obstructiva crónica, asma, silbido, tos, sibilancia pulmonar, opresión en el pecho, disnea al esfuerzo y dolor de garganta. Conclusiones: los hidrocarburos policíclicos aromáticos causan efecto deletéreo en el sistema cardiovascular y respiratorio por medio de mutaciones e inflamaciones celulares, siendo un riesgo al individuo expuesto.

Descriptores: Trabajadores; Hidrocarburos Aromáticos Policíclicos; Compuestos Orgánicos Volátiles; Enfermedades Cardiovasculares; Enfermedades Respiratorias. 


\section{INTRODUCTION}

Considering that work is an important factor in the life of a human being, it must be presented to workers in such a way as to ensure they can perform it safely. Nevertheless, workers are exposed to occupational hazards, which include chemical hazards, defined as hazards to workers who handle or are exposed to a given chemical, compound or product that can penetrate the body through inhalation, skin absorption, or ingestion, causing physical damage or harming their health ${ }^{(1)}$.

Some diseases may be associated with work involving exposure to polycyclic aromatic hydrocarbons (PAH) present in various types of smoke. Mixtures containing PAH may cause several forms of harm to the human body, such as mutagenicity and predisposition to develop cancers ${ }^{(2)}$.

$\mathrm{PAH}$ are formed from the incomplete combustion of organic material. The sources where they can be transformed are the burning of coal and fuel from vehicles, barbecue, tobacco smoke, forest burning, electrocautery smoke, among others. The types and quantities of $\mathrm{PAH}$ that will be formed depend on the ambient conditions, temperature and type of material burned ${ }^{(3)}$.

Most situations involve exposures to low doses of these compounds for long periods, which in many cases occurs throughout an individual's life and results in small increases in health risks ${ }^{(4)}$. Jobs that pose such risks are aluminum smelting, chimney sweeping, incineration of organic waste, asphalt paving, naval work and those carried out at the Surgical Center (SC).

In the SC setting, exposure to PAH occurs due to the inhalation of the surgical smoke generated by the use of electrocautery, which is used to cut and coagulate vessels, decrease perioperative bleeding and facilitate visualization of the surgical field ${ }^{(5)}$.

National and international studies have shown that surgical smoke contains volatile organic compounds (VOCs) ${ }^{(6-7)}$, especially $\mathrm{PAH}^{(7-9)}$, such as benzene, benzo(a)pyrene, anthracene, naphthalene, and toluene ${ }^{(9)}$. Therefore, surgical smoke is a potential occupational hazard, in view of the amount of harmful chemicals it contains.

The International Agency for Research on Cancer (IARC) classifies PAH as a carcinogen that can generate or enhance disordered cell growth, considering that there is no safe dose and that exposure to this substance should be fully avoided ${ }^{(10)}$.

Considering that managers and workers themselves should know the risks and damage that these compounds can cause, research should be carry out to describe the harms related to exposure to these substances, especially cardiovascular and respiratory ones.

\section{OBJECTIVES}

To identify the scientific evidence described in the literature on the development of cardiovascular and respiratory diseases due to workplace contamination by polycyclic aromatic hydrocarbons.

\section{METHODS}

\section{Ethical aspects}

Since this research did not involve human beings, it did not need ethical appreciation in accordance with current regulations.

\section{Study design}

This is an integrative review of the literature to synthesize the scientific evidence about the knowledge of cardiovascular and respiratory risks for workers exposed to $\mathrm{PAH}$.

\section{Methodological framework}

The methodological framework adopted for the development of this review consisted in developing the research question, setting exclusion and inclusion criteria, selection and search of studies in databases, information extraction and categorization, evaluation of included studies, analysis and synthesis of the data, interpretation of the results contained in the studies and presentation of the review ${ }^{(11)}$.

\section{Methodological procedure}

In order to develop the research question, the PICO format was adopted, in which $\mathrm{P}$ stands for patient or problem, I stands for intervention or indicator, $\mathrm{C}$ for comparison and $\mathrm{O}$ for outcomes. Using this format allows the definition of keywords and descriptors that will help in locating relevant studies in the respective databases. $\mathrm{P}$ was assigned to workers exposed to environmental contamination to I, PAH and VOC, $\mathrm{C}$ was not described because it was not a comparative study, and to $\mathrm{O}$, cardiovascular and respiratory diseases. In this way, the guiding question consisted of: "Workers exposed to contamination by polycyclic aromatic hydrocarbons can develop cardiovascular and respiratory diseases?".

\section{Data source}

Studies were selected after searching the databases Medical Literature Analysis and Retrieval System Online (through Pubmed), Web of Science (WoS), and Latin American and Caribbean Literature in Health Sciences (LILACS), using controlled - Medical Subject Headings (MeSH) and Health Sciences ( DeCS) - and non-controlled keywords combined with Boolean operators (AND and OR), as described in Chart 1. The search was performed from September to October 2017.

We chose the keyword workers because searches with the keywords health workers in said databases failed to find articles meeting the research objective and question.

\section{Collection and organization of data}

The inclusion criteria for primary studies were those that addressed the development of cardiovascular and respiratory diseases due to the presence of PAH and VOC, developed with humans, in the English, Spanish or Portuguese languages, with no time limit and published until October 2017. Repeated articles in databases were maintained in the one with the largest number of articles. Theses, dissertations, editorials, expert opinions and reviews were excluded.

The course of identification, selection, inclusion and exclusion of studies is described in the flowchart in Figure 1. 
Chart 1 - Crossings performed in Medline, WOS and LILACS databases, Londrina, Paraná, Brazil, 2017

\begin{tabular}{|c|c|}
\hline Database & Crossings \\
\hline Medline & 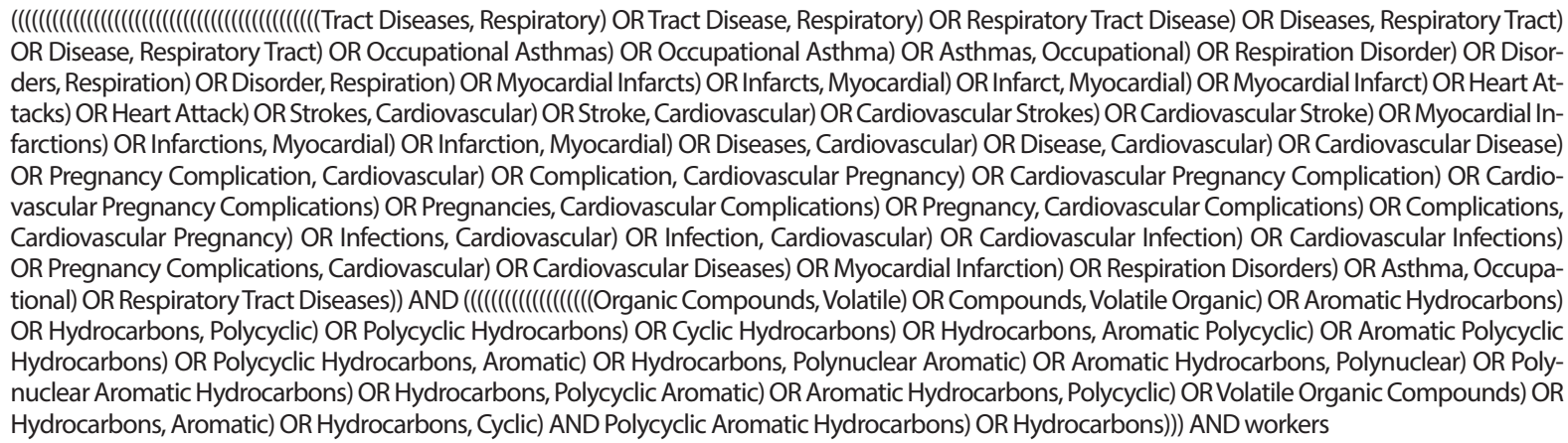 \\
\hline WoS & 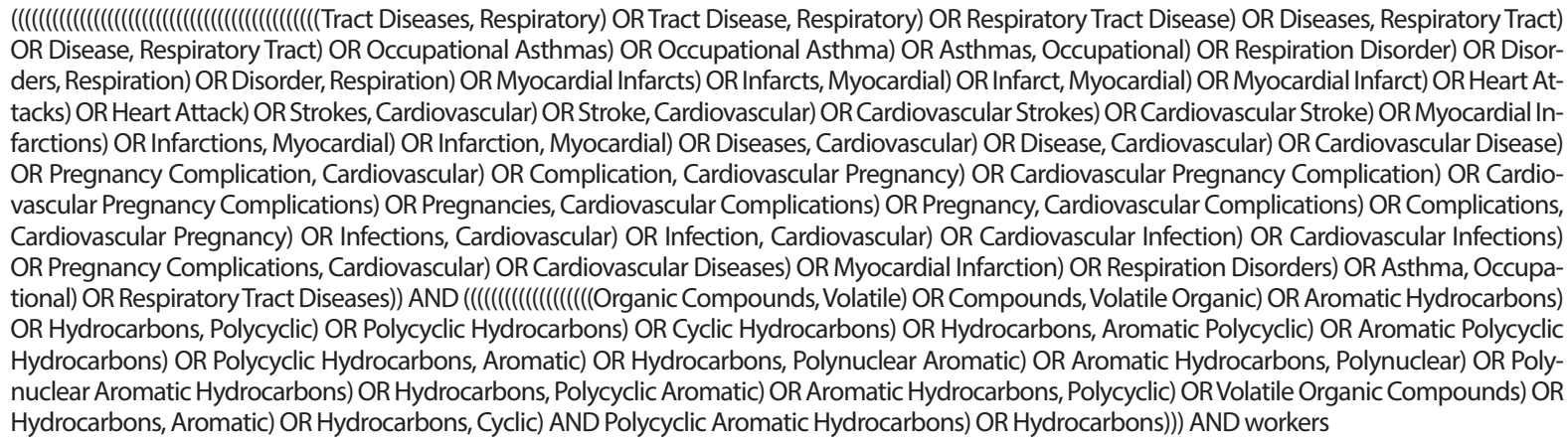 \\
\hline LILACS & $\begin{array}{l}\text { ((Hidrocarbonetos Cíclicos) OR (Hidrocarbonetos Aromáticos) OR (Hidrocarbonetos) OR (Hidrocarbonetos Aromáticos Policíclicos) OR (Compostos } \\
\text { Orgânicos Voláteis) OR (Hidrocarbonetos Policíclicos) OR (Hidrocarbonetos Policíclicos Aromáticos))AND((Doenças Cardiovasculares) OR (Sistema } \\
\text { Cardiovascular) OR (Fenômenos Fisiológicos Cardiovasculares) OR (Fenômenos Fisiológicos Circulatórios e Respiratórios) OR (Infarto do Miocárdio) } \\
\text { OR (Complicações Cardiovasculares na Gravidez) OR (Doenças Respiratórias) OR (Infecções Respiratórias) OR (Doença Pulmonar Obstrutiva Crônica) } \\
\text { OR (Asma Ocupacional) OR (Sistema Circulatório) OR (Doenças das Vias Respiratórias) OR (Doenças do Aparelho Respiratório) OR (Doenças do } \\
\text { Sistema Respiratório) OR (Doenças do Trato Respiratório) OR (Doença Respiratória) OR (Doença do Aparelho Respiratório) OR (Doença do Sistema } \\
\text { Respiratório) OR (Doença do Trato Respiratório) OR (Infecções das Vias Respiratórias) OR (Infeções do Trato Respiratório Superior) OR (Infecções } \\
\text { do Aparelho Respiratório) OR (Infecções das Vias Respiratórias Superiores) OR (Infecções das Vias Aéreas Superiores) OR (Infecções do Sistema Res- } \\
\text { piratório) OR (Infecções do Sistema Respiratório Superior) OR (Infecções do Trato Respiratório) OR (Obstrução Crônica do Fluxo Respiratório) OR } \\
\text { (Obstrução do Fluxo Respiratório Crônico) OR (Doença Obstrutiva Crônica das Vias Aéreas) OR (Doença Obstrutiva Crônica do Pulmão) OR (Doença } \\
\text { Obstrutiva Crônica Pulmonar)) }\end{array}$ \\
\hline
\end{tabular}

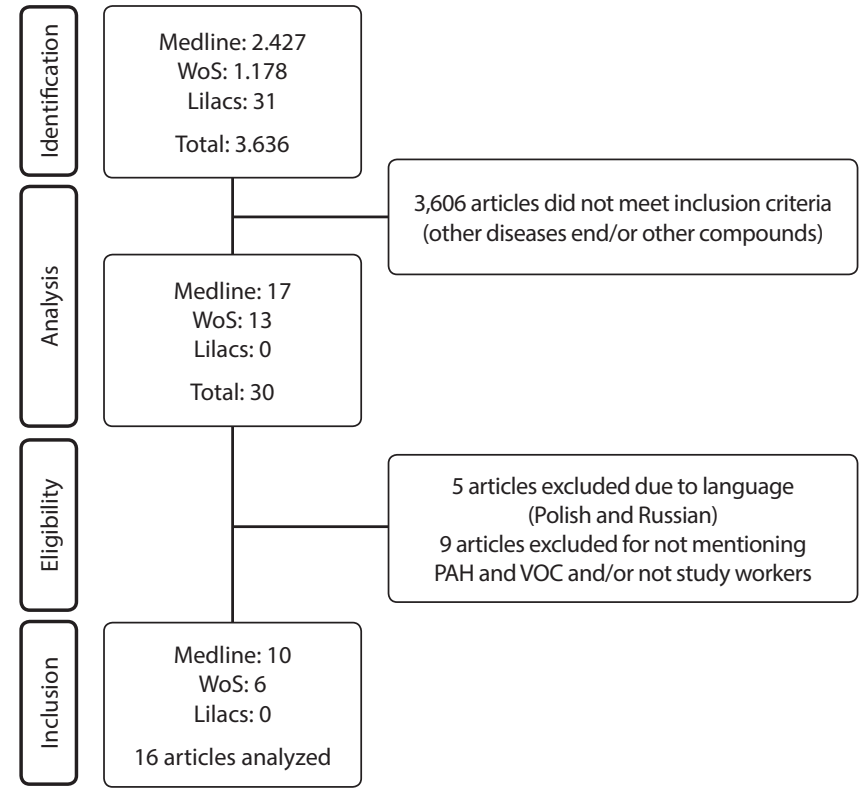

Figure 1 - Flowchart of the selection of articles found for the integrative review, Londrina, Paraná, Brazil, 2017
Studies were classified according to the level of scientific evidence. Level 1: systematic review or meta-analysis; level 2: controlled and well-designed, randomized controlled trials; level 3: controlled clinical trials without randomization; level 4: control case studies and cohort studies; level 5: systematic reviews of descriptive and qualitative studies; level 6: descriptive or qualitative studies and level 7: expert opinion ${ }^{(12)}$.

The data were extracted from the articles using a table composed of the following items: identification of articles selected according to year of publication; country of study; database; type of study; level of scientific evidence; objective and main results.

The synthesis of each study included in the review and the analyses of the results were presented descriptively in a table in the results section.

\section{RESULTS}

The integrative review was composed of 16 studies published between 1993 and 2017, in which the year with the greatest number of publications was 2016, with 4 studies (25\%). All of these studies were published in English. 
As for the method adopted, 8 (50\%) were studies with level of evidence 6 (descriptive study) and 8 (50\%) were studies with level of evidence 4 (cohort studies and case control).

In the articles analyzed, the sample studied was exclusively composed of workers exposed to PAH and VOC, of which 7 (43.7\%) on workers in coke oven, 3 (18.7\%) on asphalt workers, 2 (12.5\%) on aluminum smelter workers, 1 (6.2\%) on oil refinery workers, $1(6.2 \%)$ on restaurant kitchen workers, 1 (6.2\%) on chimney sweepers, and 1 (6.2\%) on boiler workers.

Chart 2 summarizes the main information extracted from the studies included in the review.

\section{DISCUSSION}

The studies included in this review showed evidence that exposure to PAH was associated with the presence of cardiovascular diseases and aggravations, such as increased blood pressure levels ${ }^{(22)}$, heart rate variation ${ }^{(14,24-26)}$ and ischemic heart disease ${ }^{(17,20,27)}$; and respiratory diseases such as reduced lung function $^{(23)}$, chronic obstructive pulmonary disease (COPD) $)^{(18-}$ ${ }^{19,28)}$, asthma ${ }^{(19)}$, and symptoms such as wheezing ${ }^{(16)}$, cough $^{(16,18)}$, lung wheezing $^{(19),}$ tight chest ${ }^{(19)}$, shortness of breath on exertion ${ }^{(19)}$ and sore throat ${ }^{(16)}$.

Chart 2 - Summary of studies included in the review according to year of publication, country of study, database, title and type of study, level of scientific evidence, objective and main results, Londrina, Paraná, Brazil, 2017

\begin{tabular}{|c|c|c|c|c|}
\hline $\begin{array}{l}\text { Year/ } \\
\text { Country/ } \\
\text { Database }\end{array}$ & Title & $\begin{array}{l}\text { Type of } \\
\text { study/Level } \\
\text { of scientific } \\
\text { evidence }\end{array}$ & Objective & Main results \\
\hline $\begin{array}{l}2017 \\
\text { China } \\
\text { Medline }\end{array}$ & $\begin{array}{l}\text { Effects of coke oven } \\
\text { emissions and benzo[a] } \\
\text { pyrene on blood pressure } \\
\text { and electrocardiogram in } \\
\text { coke oven workers }^{(13)} \text {. }\end{array}$ & $\begin{array}{l}\text { Descriptive } \\
\text { study } \\
\text { Level of } \\
\text { evidence: } \\
6\end{array}$ & $\begin{array}{l}\text { To evaluate the adverse } \\
\text { effects of occupational } \\
\text { exposures to coke oven } \\
\text { emissions and benzo[a] } \\
\text { pyrene on the prevalence of } \\
\text { hypertension and abnormal } \\
\text { electrocardiogram (ECG) } \\
\text { in coke workers. }\end{array}$ & $\begin{array}{l}\text { Significant increase in blood pressure levels of } \\
\text { the exposed group compared to those in the } \\
\text { control group. Exposure to benzo[a]pyrene } \\
\text { was a risk factor for hypertension in coke oven } \\
\text { workers, indicating that exposure may increase } \\
\text { the prevalence of cardiovascular disease or affect } \\
\text { blood pressure. }\end{array}$ \\
\hline $\begin{array}{l}2014 \\
\text { China } \\
\text { Medline }\end{array}$ & $\begin{array}{l}\text { Association of plasma IL-6 } \\
\text { and Hsp } 70 \text { with HRV at } \\
\text { different levels of PAHs } \\
\text { metabolites }^{(14)} \text {. }\end{array}$ & $\begin{array}{l}\text { Descriptive } \\
\text { study } \\
\text { Level of } \\
\text { evidence: } 6\end{array}$ & $\begin{array}{l}\text { Characterize how PAH can } \\
\text { induce systemic inflammation } \\
\text { and stress response, } \\
\text { contributing to altered cardiac } \\
\text { autonomic function. }\end{array}$ & $\begin{array}{l}\text { Dose-response relationships between urinary } \\
\text { PAH and interleukin- } 6 \text { metabolites and } \\
\text { interleukin- } 6 \text { indices and heart rate variation were } \\
\text { observed. An interleukin- } 6 \text { effect on heart rate } \\
\text { variation was found in groups of metabolites with } \\
\text { high levels of PAH, while high levels of heat shock } \\
\text { protein (Hsp70) may have a protective effect on } \\
\text { heart rate variation in groups with low-level of } \\
\text { PAH metabolites. }\end{array}$ \\
\hline $\begin{array}{l}2012 \\
\text { Algeria } \\
\text { Medline }\end{array}$ & $\begin{array}{l}\text { Occupational exposure to } \\
\text { petroleum products and } \\
\text { respiratory health }{ }^{(15)} \text {. }\end{array}$ & $\begin{array}{l}\text { Descriptive } \\
\text { study } \\
\text { Level of } \\
\text { evidence: } 6\end{array}$ & $\begin{array}{l}\text { To investigate the impact } \\
\text { of long-term occupational } \\
\text { exposure to PAH on } \\
\text { respiratory health. }\end{array}$ & $\begin{array}{l}\text { Aerial exposure to hydrocarbons was low. } \\
\text { Respiratory and nasal symptoms were } \\
\text { significantly more frequent among exposed } \\
\text { subjects than among controls. }\end{array}$ \\
\hline $\begin{array}{l}2011 \\
\text { China } \\
\text { Medline }\end{array}$ & $\begin{array}{l}\text { Respiratory health and } \\
\text { lung function in Chinese } \\
\text { restaurant kitchen } \\
\text { workers }^{(16)} \text {. }\end{array}$ & $\begin{array}{l}\text { Descriptive } \\
\text { study } \\
\text { Level of } \\
\text { evidence: } 6\end{array}$ & $\begin{array}{l}\text { Analyze and measure } \\
\text { concentrations of pollutants } \\
\text { such as air VOCs in Chinese } \\
\text { restaurant kitchens using } \\
\text { different types of stove and } \\
\text { assess their influence on } \\
\text { workers' respiratory health. }\end{array}$ & $\begin{array}{l}\text { The median concentrations of fine particles and } \\
\text { volatile compounds were higher in gas-fuelled } \\
\text { kitchens than in electricity-run kitchens. Workers } \\
\text { using electric stoves had significantly better lung } \\
\text { function than their gas-use counterparts. Wheeze, } \\
\text { cough and sore throat were more prevalent in } \\
\text { workers who used gas in the kitchen. }\end{array}$ \\
\hline $\begin{array}{c}2010 \\
\text { Canada } \\
\text { Medline }\end{array}$ & $\begin{array}{l}\text { Chronic and acute effects } \\
\text { of coal tar pitch exposure } \\
\text { and cardiopulmonary } \\
\text { mortality among aluminum } \\
\text { smelter workers }^{(17)} \text {. }\end{array}$ & $\begin{array}{l}\text { Longitudinal } \\
\text { study } \\
\text { Level of } \\
\text { evidence: } 4\end{array}$ & $\begin{array}{l}\text { To analyze the effects of } \\
\text { acute and chronic exposure } \\
\text { to PAH on cardiopulmonary } \\
\text { mortality. }\end{array}$ & $\begin{array}{l}\text { Mortality from ischemic heart disease was } \\
\text { associated with cumulative benzo[a]pyrene } \\
\text { exposure. A monotonic tendency with chronic } \\
\text { exposure to benzo[a]pyrene and acute } \\
\text { myocardial infarction was observed .The stronger } \\
\text { associations observed during employment } \\
\text { suggest that risk may not persist after exposure } \\
\text { cessation. }\end{array}$ \\
\hline $\begin{array}{l}2006 \\
\text { China } \\
\text { Medline }\end{array}$ & $\begin{array}{l}\text { Increased risk of chronic } \\
\text { obstructive pulmonary } \\
\text { diseases in coke oven } \\
\text { workers: interaction } \\
\text { between occupational } \\
\text { exposure and smoking }{ }^{(18)} \text {. }\end{array}$ & $\begin{array}{l}\text { Descriptive } \\
\text { study } \\
\text { Level of } \\
\text { evidence: } 6\end{array}$ & $\begin{array}{l}\text { To explore the dose-response } \\
\text { relationship between } \\
\text { exposure to coke oven } \\
\text { emissions, PAH and chronic } \\
\text { obstructive pulmonary } \\
\text { disease, and to assess } \\
\text { interaction with smoking. }\end{array}$ & $\begin{array}{l}\text { The interaction between exposure to the coke } \\
\text { oven and smoking in chronic obstructive } \\
\text { pulmonary disease was significant. The risk of } \\
\text { chronic obstructive pulmonary disease in those } \\
\text { with the highest cumulative exposure to coke } \\
\text { oven and smoking was 58-fold compared with } \\
\text { non-smokers not exposed to coke oven. }\end{array}$ \\
\hline
\end{tabular}




\begin{tabular}{|c|c|c|c|c|}
\hline $\begin{array}{l}\text { Year/ } \\
\text { Country/ } \\
\text { Database }\end{array}$ & Title & $\begin{array}{c}\text { Type of } \\
\text { study/Level } \\
\text { of scientific } \\
\text { evidence }\end{array}$ & Objective & Main results \\
\hline $\begin{array}{l}2004 \\
\text { Norway } \\
\text { Medline }\end{array}$ & $\begin{array}{l}\text { Respiratory symptoms and } \\
\text { airflow limitation in asphalt } \\
\text { workers }^{(19)} \text {. }\end{array}$ & $\begin{array}{l}\text { Descriptive } \\
\text { study } \\
\text { Level of } \\
\text { evidence: } 6\end{array}$ & $\begin{array}{l}\text { To evaluate the occurrence } \\
\text { of respiratory symptoms and } \\
\text { signs of airflow limitations in } \\
\text { a group of asphalt workers } \\
\text { exposed to PAH. }\end{array}$ & $\begin{array}{l}\text { The Forced expiratory volume and forced vital } \\
\text { capacity ratio was significantly lower in asphalt } \\
\text { workers than in controls. Symptoms of eye } \\
\text { irritation, chest tightness, shortness of breath on } \\
\text { exertion, chest wheezing, physician diagnosed } \\
\text { asthma and chronic obstructive pulmonary } \\
\text { disease were significantly more prevalent among } \\
\text { the asphalt workers. }\end{array}$ \\
\hline $\begin{array}{l}2003 \\
\text { Netherlands } \\
\text { Medline }\end{array}$ & $\begin{array}{l}\text { Polycyclic aromatic } \\
\text { hydrocarbons and fatal } \\
\text { ischemic heart disease }{ }^{(20)} \text {. }\end{array}$ & $\begin{array}{l}\text { Longitudinal } \\
\text { study } \\
\text { Level of } \\
\text { evidence: } 4\end{array}$ & $\begin{array}{l}\text { To analyze the relationship } \\
\text { between exposure to PAH and } \\
\text { mortality from systemic heart } \\
\text { disease. }\end{array}$ & $\begin{array}{l}\text { The cumulative and average exposure indices for } \\
\text { benzo[a]pyrene were positively associated with } \\
\text { mortality from ischemic heart disease (IHD). The } \\
\text { results confirm the hypothesis that occupational } \\
\text { exposure to PAH causes fatal IHD and demonstrates } \\
\text { a consistent exposure-response relation for this } \\
\text { association. }\end{array}$ \\
\hline $\begin{array}{l}1993 \\
\text { France } \\
\text { Medline }\end{array}$ & $\begin{array}{l}\text { Mortality from lung cancer } \\
\text { and cardiovascular diseases } \\
\text { among stainless-steel } \\
\text { producing workers }^{(21)} \text {. }\end{array}$ & $\begin{array}{l}\text { Longitudinal } \\
\text { study } \\
\text { Level of } \\
\text { evidence: } 4\end{array}$ & $\begin{array}{l}\text { To investigate a possible risk } \\
\text { of lung cancer in relation } \\
\text { to exposure to chromium } \\
\text { compounds, PAH and silica. To } \\
\text { examine the role of heat } \\
\text { exposure in mortality from } \\
\text { cardiovascular diseases. }\end{array}$ & $\begin{array}{l}\text { Among the exposed individuals, no lung cancer, } \\
\text { cardiovascular disease or ischemic heart disease } \\
\text { was identified. }\end{array}$ \\
\hline $\begin{array}{l}2017 \\
\text { Sweden } \\
\text { Web of } \\
\text { Science }\end{array}$ & $\begin{array}{l}\text { Early markers of } \\
\text { cardiovascular disease } \\
\text { are associated with } \\
\text { occupational exposure } \\
\text { to polycyclic aromatic } \\
\text { hydrocarbons } \\
\text { (22). }\end{array}$ & $\begin{array}{l}\text { Descriptive } \\
\text { study } \\
\text { Level of } \\
\text { evidence: } 6\end{array}$ & $\begin{array}{l}\text { To assess occupational } \\
\text { exposure to PAH between } \\
\text { chimney sweeps by } \\
\text { measuring urine metabolites } \\
\text { and identifying work tasks } \\
\text { that may be associated } \\
\text { with increased exposure } \\
\text { and to estimate the risk of } \\
\text { cardiovascular disease. }\end{array}$ & $\begin{array}{l}\text { Blood pressure (BP), urinary PAH metabolites } \\
\text { and serum biomarkers (C-reactive protein, } \\
\text { homocysteine, gamma-glutamyltransferase, } \\
\text { cholesterol, HDL, LDL and triglycerides) were } \\
\text { measured. Chimney sweeps had up to } 7 \text { times } \\
\text { higher concentrations of PAH metabolites in } \\
\text { urine than controls. Compared with controls, } \\
\text { chimney sweeps had increased homocysteine, } \\
\text { cholesterol, and HDL. PAH exposure among } \\
\text { chimney sweeps resulted in elevated levels of } \\
\text { markers for CVD risk. These findings stress the } \\
\text { need to reduce occupational exposure to PAH. }\end{array}$ \\
\hline $\begin{array}{l}2016 \\
\text { China } \\
\text { Web of } \\
\text { Science }\end{array}$ & $\begin{array}{l}\text { Polycyclic aromatic } \\
\text { hydrocarbons exposure } \\
\text { and lung function decline } \\
\text { among coke-oven workers: } \\
\text { a four-year follow up } \\
\text { study }^{(23)} \text {. }\end{array}$ & $\begin{array}{l}\text { Longitudinal } \\
\text { study } \\
\text { Level of } \\
\text { evidence: } 4\end{array}$ & $\begin{array}{l}\text { To investigate the quantitative } \\
\text { relationships of urinary PAH } \\
\text { metabolites with decreased } \\
\text { lung function among coke } \\
\text { oven workers. }\end{array}$ & $\begin{array}{l}\text { Higher levels of baseline PAH exposure may lead } \\
\text { to a further decline in lung function over a four- } \\
\text { year follow-up. }\end{array}$ \\
\hline $\begin{array}{l}2016 \\
\text { China } \\
\text { Web of } \\
\text { Science }\end{array}$ & $\begin{array}{l}\text { Polycyclic aromatic } \\
\text { hydrocarbon exposure, } \\
\text { miR 146a rs } 2910164 \\
\text { polymorphism, and heart } \\
\text { rate variability in coke oven } \\
\text { workers }^{(24)} \text {. }\end{array}$ & $\begin{array}{l}\text { Descriptive } \\
\text { study } \\
\text { Level of } \\
\text { evidence: } 6\end{array}$ & $\begin{array}{l}\text { To investigate the influences } \\
\text { of four simple nucleotide } \\
\text { polymorphisms in heart } \\
\text { rate variability (HRV) and } \\
\text { its modifying effects on } \\
\text { the associations between } \\
\text { exposure to PAH. }\end{array}$ & $\begin{array}{l}\text { Coke oven workers with rs } 2910164 \text { CC genotype had } \\
\text { significant lower HRV. Considering the crucial role of } \\
\text { automatic cardiac dysfunction in the pathogenesis of } \\
\text { cardiovascular diseases, the occupational population } \\
\text { exposed to PAH with miR-146a rs } 2910164 \text { CC } \\
\text { genotype may be at increased risk for developing } \\
\text { cardiovascular diseases. }\end{array}$ \\
\hline $\begin{array}{l}2016 \\
\text { China } \\
\text { Web of } \\
\text { Science }\end{array}$ & $\begin{array}{l}\text { Exposure to polycyclic } \\
\text { aromatic hydrocarbons, } \\
\text { plasma cytokines, and } \\
\text { heart rate variability }{ }^{(25)} \text {. }\end{array}$ & $\begin{array}{l}\text { Case-control } \\
\text { study } \\
\text { Level of } \\
\text { evidence: } 4\end{array}$ & $\begin{array}{l}\text { To examine differences } \\
\text { in plasma cytokine } \\
\text { concentrations among coke } \\
\text { oven workers and community } \\
\text { residents. }\end{array}$ & $\begin{array}{l}\text { The results indicated that PAH exposure was } \\
\text { associated with plasma cytokines. Higher } \\
\text { cytokines were associated with decreased heart } \\
\text { rate. }\end{array}$ \\
\hline $\begin{array}{l}2016 \\
\text { China } \\
\text { Web of } \\
\text { Science }\end{array}$ & $\begin{array}{l}\text { Polycyclic aromatic } \\
\text { hydrocarbons - associated } \\
\text { microRNAs and heart rate } \\
\text { variability in coke oven } \\
\text { workers }{ }^{(26)} \text {. }\end{array}$ & $\begin{array}{l}\text { Case-control } \\
\text { study } \\
\text { Level of } \\
\text { evidence: } 4\end{array}$ & $\begin{array}{l}\text { To assess the association } \\
\text { between PAH-related } \\
\text { microRNAs (miRNAs) and } \\
\text { heart rate variability indices in } \\
\text { coke oven workers. }\end{array}$ & $\begin{array}{l}\text { MiR-24-3p, miR-27a-3p, miR-142-5p and miR- } \\
320 b \text { were negatively associated with successive } \\
\text { differences between adjacent normal NN intervals } \\
\text { (RMSSD). MiR-142-5p and miR-320b were also } \\
\text { negatively associated with the standard deviation of } \\
\text { all normal to normal NN intervals (SDNN). MiR-24-3p, } \\
\text { miR-27a-3p and miR-320b interacted significantly } \\
\text { with multiple PAH metabolites and influenced heart } \\
\text { rate variability indices. In conclusion, plasma miRNAs } \\
\text { might act as potential biomarkers for the adverse } \\
\text { effect of PAH exposure on the cardiovascular system. }\end{array}$ \\
\hline
\end{tabular}




\begin{tabular}{|c|c|c|c|c|}
\hline $\begin{array}{l}\text { Year/ } \\
\text { Country/ } \\
\text { Database }\end{array}$ & Title & $\begin{array}{l}\text { Type of } \\
\text { study/Level } \\
\text { of scientific } \\
\text { evidence }\end{array}$ & Objective & Main results \\
\hline $\begin{array}{c}2011 \\
\text { USA } \\
\text { Web of } \\
\text { Science }\end{array}$ & $\begin{array}{l}\text { Cardiac autonomic } \\
\text { dysfunction from } \\
\text { occupational exposure } \\
\text { to polycyclic aromatic } \\
\text { hydrocarbons }^{(27)} \text {. }\end{array}$ & $\begin{array}{l}\text { Longitudinal } \\
\text { study } \\
\text { Level of } \\
\text { evidence: } 4\end{array}$ & $\begin{array}{l}\text { To investigate the association } \\
\text { between PAH and heart rate } \\
\text { variability in boilermakers. }\end{array}$ & $\begin{array}{l}\text { Occupational exposure to PAH is } \\
\text { associated with altered cardiac autonomic } \\
\text { function. Acute exposure to PAH may be an } \\
\text { important predictor of cardiovascular disease risk } \\
\text { in the work environment. }\end{array}$ \\
\hline $\begin{array}{l}2003 \\
\text { USA } \\
\text { Web of } \\
\text { Science }\end{array}$ & $\begin{array}{l}\text { Mortality from obstructive } \\
\text { lung diseases and exposure } \\
\text { to polycyclic aromatic } \\
\text { hydrocarbons among } \\
\text { asphalt workers }{ }^{(28)} \text {. }\end{array}$ & $\begin{array}{l}\text { Longitudinal } \\
\text { study } \\
\text { Level of } \\
\text { evidence: } 4\end{array}$ & $\begin{array}{l}\text { The relationships between } \\
\text { mortality from non-malignant } \\
\text { respiratory diseases and PAH. }\end{array}$ & $\begin{array}{l}\text { The results show that PAH exposures, originating } \\
\text { mainly from coal tar and possibly from bitumen } \\
\text { fume, may have contributed to mortality from } \\
\text { obstructive lung diseases among asphalt workers. }\end{array}$ \\
\hline
\end{tabular}

Cardiovascular and respiratory diseases are the main health problems worldwide. In 2015, they were the leading causes of death in the world, followed by lung diseases and lung and tracheal neoplasms ${ }^{(29)}$.

In all studies that have addressed cardiac abnormalities, PAH act so as to develop from acute to chronic changes in cardiac function.

It is already recognized that exposure to environmental particulate matter, such as PAH, contributes to adverse health effects and is a risk factor for the development of ischemic cardiovascular diseases due to increased atherosclerosis, coronary artery disease and myocardial infarction. Particles smaller than $10 \mu m$ exert an adverse effect by adhering to lung tissue and crossing into the systemic circulation ${ }^{(30)}$.

A study indicated that $95 \%$ of $\mathrm{PAH}$ are related to particles smaller than $10 \mu \mathrm{m}$ in diameter and are considered inhalable and increase the possibility of absorption by the organism due to the ease of intrathoracic deposition. Smaller particles remain for longer in this region, because the PAH disposal processes linked to particles are slow, so they can remain for weeks and even years in direct contact with the alveolar membrane ${ }^{(31)}$.

Exposure to high levels of PAH was associated with morbidity, mortality, or prevalence of cardiovascular disease through inflammation $^{(14)}$. Among PAH-exposed groups, an increase of about $60 \%$ in the mortality risk from ischemic heart disease can be demonstrated by the mechanisms involved in the development of atherosclerotic plaques by mutations induced by PAH or other carcinogens ${ }^{(20)}$.

Increased exposure to PAH may cause a decrease in autonomic cardiac function, which is one of the main pathophysiologic pathways of adverse cardiac events mediated by pollution ${ }^{(32)}$. Thus, systemic inflammation may be one of the mechanisms that link air pollution to cardiovascular autonomic decline, evidencing the significant dose-dependent relationship between urinary PAH metabolites and inflammatory markers ${ }^{(14)}$.

Some PAH, such as benzo[a]pyrene, can access the central nervous system (CNS), cross the blood-brain barrier or through the olfactory nerve and attach to the cerebellum, thus involving cardiovascular modulation. They may also activate changes in the cardiac ion channel leading to such acute cardiovascular effects as the incidence of acute myocardial infarction, and the effect of oxidative stress can lead to autonomic cardiac imbalance ${ }^{(27)}$. In addition, it is observed that there was a significant increase in blood pressure levels in a group exposed to benzo[a]pyrene, which a risk factor for cardiovascular diseases ${ }^{(25)}$.

Respiratory problems caused by PAH exposure are associated with the inhalation of air polluted by this component and exposed workers may develop diseases such as asthma, COPD and lung cancer ${ }^{(33)}$.

$\mathrm{PAH}$ were found to deposit in the alveolar epithelium through inhalation, causing toxic effects on respiratory cells and, through the metabolism of $\mathrm{PAH}$, produce free radicals that lead to inflammatory responses, damaging the respiratory system ${ }^{(34)}$.

Cytokines and other substances secreted by inflammatory cells are the factors that contribute to airway inflammation and lung function decline through the development of structural changes of the airways ${ }^{(23)}$.

It was verified that there was difference in the pulmonary function among $\mathrm{PAH}$-exposed workers, i.e. effects of decline over the years ${ }^{(23)}$, for they present with more respiratory symptoms, lower lung function and signs of airway inflammation, even at low levels of exposure ${ }^{(15)}$.

Cumulative and medium exposures to $\mathrm{PAH}$ are positively associated with mortality from COPD ${ }^{(28)}$. Studies have indicated that PAH do not act directly with the genetic material after being absorbed by the body, they are instead activated through the metabolic process, in which there is the formation of watersoluble compounds to facilitate the excretion process and, in this way, these metabolites interact with the genetic material of cells giving rise to the process of tumoration or mutation ${ }^{(2-3)}$.

The studies found in this review were carried out with asphalt, naval, smelt and kitchen workers. However, it should be pointed out that the health worker, especially the surgical center worker, also has a real exposure to $\mathrm{PAH}$. Indeed, a recent study was conducted with surgical workers to compare the prevalence of signs and symptoms related to inhalation of surgical smoke among surgical technologists and non-surgical technologists nursing professionals. As a result, a statistical significance was found as regards the presence of eye irritation ( $p=0.02)$, nasal mucosa and oral cavity irritation $(p=0.03)$ and headache $(p=0.04)$, when comparing surgical and non-surgical technologists nursing professionals ${ }^{(35)}$.

Workers in the operating room are not continuously exposed during surgery, because the electrocautery is used at specific 
times during the surgical procedure. As shown, there is statistically significant evidence that workers closer to the operative field are susceptible to this exposure.

Another study conducted by the same group of researchers was designed to analyze the concentrations of PAH from electrocautery smoke and the use of personal protective equipment by the intraoperative team when exposed to $\mathrm{PAH}$. As a result, naphthalene was found to be present in $96 \%$ of surgeries and phenanthrene in $98 \%$, with a strong correlation $(0.761, \mathrm{p}<0.001)$ between these compounds. With these results, the authors emphasize that the recommended masks (N95) were not used by the intraoperative team in the operating room ${ }^{(9)}$.

Even with the campaign of the Association of Perioperative Registered Nurses (Aorn) showing the need to use this personal protective equipment when exposed to electrocautery smoke, workers are unaware of the risk to which they are exposed. Another knowledge gap is the determination of the time of exposure to surgical smoke required to develop signs and symptoms related to inhalation of this smoke, in addition to the development of validated instruments for collecting these data. In this sense, Brazilian researchers from the research group Núcleo de Estudos de Saúde do Trabalhador da Universidade Estadual de Londrina (Nuestuel) has been developing studies on this subject for the last 5 years, so as to increase the protection of workers exposed to this chemical hazard and respond to these knowledge gaps.

\section{Limitations of the study}

The limitation of this study refers to studies found in the databases with methods that characterized scientific evidence of levels 4 and 6.

\section{Contributions to the area of nursing, health or public policy}

From this literature review, it can be seen that PAH present in the combustion of organic matter are harmful to the cardiovascular and respiratory health of workers exposed to these substances. Thus, the findings of this review contribute to improve the scientific knowledge about the subject, which is still little explored in the field of national health and nursing.

\section{FINAL CONSIDERATIONS}

PAH-exposed workers can develop cardiovascular and respiratory illnesses and diseases. There is scientific evidence that PAH causes deleterious effects on the cardiovascular and respiratory systems through mutations and cellular inflammation and is a risk to any individual exposed to these compounds. Thus, preventive measures at the organizational level need to be taken to protect workers exposed to these substances.

\section{REFERENCES}

1. Ministério do Trabalho (BR). Portaria Ministério do Trabalho no 871, de 6 de julho de 2017. Atualiza a NR 9 - Programa de Prevenção de Riscos Ambientais [Internet]. Brasília; 2017 [cited 2018 Nov 18]. Available from: http://trabalho.gov.br/images/Documentos/SST/NR/NR09/ NR-09-2016.pdf

2. Bernardo DL, Barros KA, Silva RC, Pavão AC. Carcinogenicidade de hidrocarbonetos policíclicos aromáticos. Quim Nova. 2016;39(7):789-94. doi: http://dx.doi.org/10.5935/0100-4042.20160093

3. Caruso MSF, Alaburda J. Hidrocarbonetos policíclicos aromáticos - benzo(a)pireno: uma revisão. Rev Inst Adolfo Lutz [Internet]. 2008[cited 2018 Nov 18];67(1):1-27. Available from: https://biblat.unam.mx/pt/revista/revista-do-instituto-adolfo-lutz/articulo/ hidrocarbonetos-policiclicos-aromaticos-benzoapireno-uma-revisao

4. Franco SS, Nardocci AC, Gunther WMR. Biomarcadores de HPAs na avaliação de risco à saúde humana: uma revisão do estado da arte. Cad Saude Publica. 2008;24(4):a569-s580. doi: http://dx.doi.org/10.1590/S0102-311X2008001600009

5. Bhatt A, Mittal S, Gopinath KS. Safety considerations for health care workers involved in cytoreductive surgery and perioperative chemotherapy. Indian J Surg Oncol. 2016;7(2):249-57. doi: http://dx.doi.org/10.1007/s13193-016-0503-7

6. Choi SH, Kwon TG, Chung SK, Kim TH. Surgical smoke may be a biohazard to surgeons performing laparoscopic surgery. Surg Endosc. 2014;28(8):2374-80. doi: http://dx.doi.org/10.1007/s00464-014-3472-3

7. Tramontini CC, Galvão CM, Claudio CV, Ribeiro RP, Martins JT. Composição da fumaça produzida pelo bisturi elétrico: revisão integrativa da literatura. Rev Esc Enferm USP. 2016;50(1):144-53. doi: http://dx.doi.org/10.1590/S0080-623420160000100019

8. Tseng HS, Liu SP, Uang SN, Yang LR, Lee SC, Liu YJ et al. Cancer risk of incremental exposure to polycyclic aromatic hydrocarbons in electrocautery smoke for mastectomy personnel. World J Surg Oncol. 2014;12:31. doi: http://dx.doi.org/10.1186/1477-7819-12-31

9. Claudio CV, Ribeiro RP, Martins JT, Marziale MH, Solci MC, Dalmas JC. Polycycic aromatic hydrocarbons produced by electrocautery smoke and the use of personal protective equipment. Rev Latino-Am Enfermagem. 2017;25:e2853. doi: http://dx.doi. org/10.1590/1518-8345.1561.2853

10. International Agency for Research on Cancer. European Code Against Cancer: 12 ways to reduce your cancer risk [Internet]. 2015 [cited 2019 Apr. 17]. Available from: https://cancer-code-europe.iarc.fr/index.php/en/ecac-12-ways/ pollutants-recommendation/165-any-safe-dose-of-exposure-to-cancer-causing-chemical-substances

11. Mendes KDS, Silveira RCCP, Galvão CM. Revisão integrativa: método de pesquisa para a incorporação de evidências na saúde e na enfermagem. Texto Contexto Enferm. 2008;17(4):758-64. doi: 10.1590/S0104-07072008000400018

12. Fineout-Overholt E, Stillwell SB. Asking compelling, clinical questions. In: Melnyk BM, Fineout-Overholt E. Evidence-based practice in nursing \& healthcare: a guide to best practice. Philadelphia: Wolters Kluwer; 2011. p. 25-39. 
13. Yang K1, Jiang X, Cheng S, Chen C, Cao X, Tu B. Effects of coke oven emissions and benzo[a]pyrene on blood pressure and electrocardiogram in coke oven workers. J Occup Health. 2017;59(1):1-7. doi: http://dx.doi.org/10.1539/joh.15-0264-OA

14. Ye J, Zhu R, He X, Feng Y, Yang L, Zhu X et al. Association of Plasma IL-6 and Hsp 70 with HRV at Different Levels of PAHs Metabolites. PLoS ONE. 2014;9(4):e92964. doi: http://dx.doi.org/10.1371/journal.pone.0092964

15. Sekkal S, Haddam N, Scheers H, Poels KL, Bouhacina L, Nawrot TS et al. Occupational exposure to petroleum products and respiratory health: a cross sectional study from Algeria. J Occup Environ Med. 2012;54(11):1382-8. doi: http://dx.doi.org/10.1097/ JOM.0b013e31825fa6c9

16. Wong TW, Wong AH, Lee FS, Qiu H. Respiratory health and lung function in Chinese restaurant kitchen workers. Occup Environ Med. 2011;68(10):746-52. doi: http://dx.doi.org/10.1136/oem.2010.059378

17. Friesen MC, Demers PA, Spinelli JJ, Eisen EA, Lorenzi MF, Le ND. Chronic and acute effects of coal tar pich exposure and cardiopulmonary mortality among aluminum smelter workers. Am J Epidemiol. 2010;172(7):790-9. doi: http://dx.doi.org/10.1093/aje/kwq208

18. Hu Y, Chen B, Yin Z, Jia L, Zhou Y, Jin T. Increased risk of chronic obstructive pulmonary diseases in coke oven workers: interaction between occupational exposure and smoking. Thorax. 2006;61(4):290-5. doi: http://dx.doi.org/10.1136/thx.2005.051524

19. Randem BG, Ulvestad B, Burstyn I, Kongerud J. Respiratory symptons and airflow limitation in asphalt workers. Occup Environ Med. 2004;61(4):367-9. doi: http://dx.doi.org/10.1136/oem.2002.006114

20. Burstyn I, Kromhout H, Partanen T, Svane O, Langård S, Ahrens W et al. Polycyclic Aromatic Hydrocarbons and fatal ischemic heart disease. Epidemiol. 2005;16(6):744-50.

21. Moulin JJ, Wild P, Mantout B, Fournier-Betz M, Mur JM, Smagghe G. Mortality from lung cancer and cardiovascular diseases among stainlesssteel producing workers. Cancer Causes Control. 1993;4(2):75-81.

22. Alhamdow A, Lindh C, Albin M, Gustavsson P, Tinnerberg H, Broberg K. Early markers of cardiovascular disease are associated with occupational exposure to polycyclic aromatic hydrocarbons. Sci Rep. 2017;7:9426. doi: http://dx.doi.org/10.1038/s41598-017-09956-x

23. Wang S, Bai Y, Deng Q, Chen Z, Dai J, Li X et al. Polycyclic aromatic hydrocarbons exposure and lung function decline among coke-oven workers: a four-year follow up study. Environ Res. 2016;150:14-22. doi: http://dx.doi.org/10.1016/j.envres.2016.05.025

24. Deng Q, Guo H, Deng N, Zhang W, Li X, Deng H et al. Polycyclic aromatic hydrocarbon exposure, miR-146a rs2910164 polymorphism, and heart rate variability in coke oven workers. Environ Res. 2016;148:277-84. doi: http://dx.doi.org/10.1016/j.envres.2016.04.014

25. Yang B, Deng Q, Zhang W, Feng Y, Dai X, Feng W et al. Exposure to polycyclic aromatic hydrocarbons, plasma cytokines, and heart rate variability. Sci Rep. 2016;6:19272. doi: http://dx.doi.org/10.1038/srep19272

26. Huang S, Deng Q, Feng J, Zhang X, Dai X, Li L et al. Polycyclic aromatic hydrocarbons, associated MicroRNAs and heart rate variability in coke oven workers. J Occup Environ Med. 2016;58(1):e24-31. doi: http://dx.doi.org/10.1097/JOM.0000000000000564

27. Lee MS, Magari S, Christiani DC. Cardiac autonomic dysfunction from occupational exposure to polycyclic aromatic hydrocarbons. Occup Environ Med. 2011;68(7):474-8. doi: http://dx.doi.org/10.1136/oem.2010.055681

28. Burstyn I, Boffetta P, Heederik D, Partanen T, Kromhout H, Svane O et al. Mortality from obstructive lung diseases and exposure to polycyclic aromatic hydrocarbons among asphalt workers. Am J Epidemiol [Internet]. 2003[cited 2018 Nov 18];158(5):468-78. Available from: https:// www.ncbi.nlm.nih.gov/pubmed/12936902

29. Organização Pan-Americana de Saúde/Organização Mundial da Saúde Brasil. 10 principais causas de morte no mundo [Internet]. Brasília; 2018. [cited 2018 Aug. 18]. Available from: https://www.paho.org/bra/index. php?option=com_content\&view=article\&id=5638:10-principais-causas-de-morte-no-mundo\&ltemid=0

30. Araujo JA, Barajas B, Kleinman M, Wang X, Bennett BJ, Gong KW et al. Ambient particulate pollutants in the ultrafine range promote early atherosclerosis and systemic oxidative stress. Circ Res. 2008;102(5):589-96. doi: http://dx.doi.org/10.1161/CIRCRESAHA.107.164970

31. Alp E, Bijl D, Bleichrodt RP, Hansson B, Voss A. Surgical smoke and infection control. J Hosp Infect. 2006;62 (1):1-5. doi: http://dx.doi. org/10.1016/j.jhin.2005.01.014

32. Rich DQ, Zareba W, Beckett W, Hopke PK, Oakes D, Frampton MW et al. Are ambient ultrafine, accumulation mode, and fine particles associated with adverse cardiac responses in patients undergoing cardiac rehabilitation? Environ Health Perspect. 2012;120(8):1162-9. doi: http://dx.doi.org/10.1289/ehp.1104262

33. Armstrong B, Hutchinson E, Unwin J, Fletcher T. Lung cancer risk after exposure to polycyclic aromatic hydrocarbons: a review and metaanalysis. Environ Health Perspect. 2004;112(9):970-8. doi: http://dx.doi.org/10.1289/ehp.6895

34. Fu PP, Xia Q, Sun X, Yu H. Phototoxicity and environmental transformation of polycyclic aromatic hydrocarbons (PAHs)-light-induced reactive oxygen species, lipid peroxidation, and DNA damage. J Environ Sci Health C Environ Carcinog Ecotoxicol Rev. 2012;30(1):1-41. doi: http://dx.doi.org/10.1080/10590501.2012.653887

35. Saito AC, Margatho AS, Bieniek AA, Stanganelli NC, Ribeiro RP. Sinais e sintomas relacionados à inalação da fumaça cirúrgica na equipe de enfermagem. Esc Anna Nery. 2019;23(3):1-6. doi: http://dx.doi.org/10.1590/2177-9465-ean-2018-0292 